\title{
TAX AVOIDENCE (PENGHINDARAN PAJAK) OLEH WAJIB PAJAK DALAM PERSFEKTIF ISLAM
}

\author{
Ali murtado Emzaed ${ }^{\mathrm{a}, 1, *}$, H, Syaikhu ${ }^{\mathrm{b}, 2}$, Elvi Soeradji ${ }^{\mathrm{c}, 3}$, Norwilid ${ }^{\mathrm{d}, 4}$, Munib ${ }^{\mathrm{e}, 5}$, Erry Fitria ${ }^{\mathrm{f}, 6}$ \\ aalimurtadhoemzaed@gmail.com, ${ }^{1}$ IAIN Palangka Raya, Indonesia, \\ ${ }^{b}$ syaikhu.ahmad.h@gmail.com, ${ }^{2}$ IAIN Palangka Raya,Indonesia, \\ celvisoeradji@gmail.com, ${ }^{3}$ IAIN Palangka Raya, Indonesia, \\ dnorwili.syariah@gmail.com, ${ }^{4}$ IAIN Palangka Raya, Indonesia, \\ eibintirta@yahoo.co.id, ${ }^{5}$ IAIN Palangka Raya, Indonesia, \\ ferry.fit@gmail.com, ${ }^{6}$ IAIN Palangka Raya, Indonesia
}

ABSTRACT

Tax Avoidance has a broad spectrum of issues, one of which is transfer pricing. Transfer pricing is one way that used by the tax payer of multinational corporations to avoid taxes. Transfer pricing is not seen as a behavior that violates the Indonesian legal norms. Yet this behavior has clearly eroded the state revenue from the tax sector. There is a serious gap between the level of substance which is the goal of law (doelmatigheid) with the level of legal certainty (rechtsmatigheid). At the level of the legal objective that the tax rules are meant for tax collection, whereas in the level of legal certainty that tax evasion is not categorized as an act contrary to the rules of taxation itself. This means that tax evasion contradicts the objectives of the tax law. Researchers look at this issue from the perspective of Islamic uokum based on the normative approach of argumentative. This study has found the existence of bad I'tikad of taxpayers in fulfilling the obligation to pay taxes.

Keywords: Tax, Tax Avoidance, Taxpayer, Good intention

\section{ABSTRAK}

Tax Avoidance mempunyai spektrum persoalan yang luas, salah satunya adalah transfer harga (transfer pricing). Transfer pricing merupakan salah satu cara yang dipakai oleh wajib pajak perusahaan multinasional untuk melakukan penghindaran pajak. Perilaku transfer pricing ini tidak dipandang sebagai perilaku yang melanggar norma hukum positif yang berlaku di negara kita. Padahal perilaku ini jelas-jelas telah menggerus pendapatan negara dari sektor perpajakan. Ada gap yang serius antara aras substansi yang menjadi tujuan hukum (doelmatigheid) dengan aras kepastian hukum(rechtsmatigheid). Pada aras tujuan hukum bahwa aturan perpajakan dimaksudkan untuk pengumpulan pajak, sedangkan pada aras kepastian hukum bahwa penghindaran pajak tidak dikategorikan sebagai perbuatan yang bertentangan dengan aturan perpajakan itu sendiri. Artinya penghindaran pajak bertentangan dengan tujuan hukum perpajakan. Peneliti melihat persoalan ini dari perspektif hukum Islam yang didasarkan pada pendekatan normatif argumentatif. Penelitian ini telah menemukan adanya I'tikad tidak baik dari wajib pajak dalam memenuhi kewajibanya membayar pajak.

Kata Kunci: Pajak, Penghindaran Pajak, Wajib pajak, I'tikad baik

\section{A. Pendahuluan}

Penelitian ini berangkat dari pemikiran bahwa pajak merupakan kewajiban agama dan negara. Meskipun pada kenyataanya, wajib pajak baik pribadi atau perusahaan masih banyak 
yang menganggap bahwa pajak merupakan beban yang harus dipikulnya. Sehingga wajar jika wajib pajak membayar pajak secara tidak sukarela, sebab pajak adalah suatu beban yang akan mengurangi kemampuan ekonomisnya. ${ }^{1}$

Pajak adalah iuran yang sifatnya memaksa. Negara tidak membutuhkan kerelaan wajib pajak. Akan tetapi negara membutuhkan kepatuhannya, yang penting wajib pajak telah membayar pajak sesuai dengan ketentuan yang berlaku. Pemahaman pajak merupakan beban yang harus ditanggung oleh wajib pajak, akan memunculkan berbagai upaya wajib pajak untuk melakukan penghindaran pajak. Fenomena munculnya skandal Panama Peapers misalnya-yang melibatkan ratusan pengusaha Indonesia- ditengarai merupakan bentuk penghindaran pajak. Sekandal ini bukanlah perkara yang baru. Selama 50 tahun terakhir, penghindaran pajak dengan memanfaatkan negara tax haven telah mengalami peningkatan yang sangat signifikan. ${ }^{2}$

Panama Papers merupakan dokumen panama yang memuat jutaan data perusahaanperusahaan di seluruh dunia dengan jumlah tidak kurang dari 11,5 juta dokumen. Dokumen Panama ini didirikan oleh sebuah perusahaan yang berasal dari Panama dengan nama Mossack Fonseca. Sebagai penyedia jasa pendirian perusahaan "abal-abal", perusahaan ini telah berhasil mendirikan 214.000 perusahaan luar negeri sejak tahun 1977 dengan perkiraan nilai kekayaan mencapai 7,6 triliun dolar AS (setara Rp 102.600 triliun). ${ }^{3}$ Untuk menghilangkan jejak dari pengendusan otoritas pajak ataupun lembaga penyidik dari negara asal peserta pengguna jasa perusahaan ini, pihak penyedia jasa telah membangun sistem keuangan yang rumit dengan melibatkan lembaga-lembaga besar perbankan dunia yakni Deutsche Bank, HSBC, Société Générale, Credit Suisse, UBS, dan Commerzbank ${ }^{4}$ untuk "mengamankan" data-data nasabah yang memarkirkan uangnya dengan alasan kerahasiaan bank.

Menurut AH Maftuchan (Koordinator Forum Pajak Berkeadilan) bahwa skandal Panama Papers menunjukkan bahwa dunia sudah berada di era darurat kejahatan pajak. Hal ini harus menjadi momentum bagi Pemerintah Indonesia untuk segera membasmi praktik penghindaran pajak, pengelakan pajak dan praktik pencucian uang oleh wajib pajak Indonesia, baik perorangan maupun badan hukum ${ }^{5}$. Mengingat pajak adalah beban (yang akan mengurangi laba bersih penghasilan atau perusahaan) maka wajib pajak akan berupaya semaksimal mungkin agar dapat membayar pajak sekecil mungkin dan berupaya untuk menghindari pajak ${ }^{6}$ atau bahkan tidak membayar pajak.

Perilaku tax avoidance (penghindaran pajak ) dalam pandangan hukum positif (hukum perpajakan) tidak termasuk domain yang melanggar norma hukum. Padahal perilaku ini jelasjelas telah menggerus pendapatan negara dari sektor perpajakan. Terdapat gap yang serius antara substansi yang menjadi tujuan dan sasaran hukum (doelmatigheid) norma hokum (rechtsmatigheid). Pada aras tujuan hukum bahwa aturan perpajakan dimaksudkan untuk pengumpulan pajak, sedangkan pada aras kepastian hukum bahwa penghindaran pajak tidak dikategorikan sebagai perbuatan yang bertentangan dengan aturan perpajakan itu sendiri. Hal tersebut dapat diartikan penghindaran pajak bertentangan dengan tujuan hukum perpajakan.

${ }^{1}$ Reskino, Rini, dan D. Novitasari. 2013. Persepsi Mahasiswa Akuntansi Mengenai Penggelapan Pajak. Makalah disajikan dalam Simposium Nasional Perpajakan IV. Bangkalan.

${ }^{2}$ Brian J Arnold dalam Inside Tax, Edisi 38 , Mei 2016

${ }^{3}$ http://nasional.republika.co.id/berita/nasional/umum/16/04/11/o5g8a0330-panama-papers-dan-praktikpenghindaran-pajak. Diakses 10 Agustus 2016

${ }^{4}$ Wikipedia. Diakses 10 Agustus 2016

${ }^{5}$ Loc.Cit.

${ }^{6} \mathrm{Ibid}$. 
Peneliti melihat persoalan ini dari perspektif hukum Islam dengan menggunakan pendekatan normatif argumentatif.

\section{B. Pembahasan \\ 1. Tax Avoidance}

Kamus Besar Bahasa Indonesia mengartikan Istilah "penghindaran" berasal dari kata kerja "hindar" yang berarti menjauhkan diri dari; mengelak; menyingkir; menyisi; mengelak supaya terlepas. ${ }^{7}$ Sedangkan di dalam Oxford Advanced Learner's Dictionary of Current English; avoidance; the action of avoiding somebody or something, tax avoiding; arranging one's affair so as to pay the smallest amount of tax required by the law. ${ }^{8}$ Penghindaran pajak diartikan sebagai tindakan perencanaan pajak untuk membayar pajak terkecil dari yang ditetapkan oleh undang-undang.

Tax Avoidance mempunyai spektrum persoalan yang sangat luas, setidaknya ada tiga cara yang dipakai oleh wajib pajak untuk melakukan penghindaran pajak, yaitu wajib pajak menahan diri untuk tidak membeli barang-barang yang terkena pajak, melakukan transfer harga (transfer pricing), dan melakukan penghindaran pajak secara yuridis yang dikenal dengan istilah perencanaan pajak. Transfer pricing didefinisikan sebagai jumlah harga atas penyerahan barang atau imbalan atas penyerahan jasa yang telah di sepakati oleh kedua belah pihak dalam transaksi bisnis finansial maupun transaksi lainnya. ${ }^{9}$ Adapula yang mendefinisikan transfer pricing dalam pengertian transfer harga dengan cara menentukan harga atau imbalan sehubungan dengan penyerahan barang, jasa atau pengalihan teknologi antar perusahaan yang mempunyai hubungan istimewa. ${ }^{10}$ Transfer harga ini tidak mempunyai tujuan untuk menghindari pajak, meskipun sebagai wajib pajak terhindar dari bayar pajak. Definisi ini merupakan definisi dasar yang belum mengalami perubahan orientasi maksud dan tujuan dari transfer pricing.

Efek dari globalisasi tidak hanya mempengaruhi gaya hidup manusia, akan tetapi mempengaruhi juga terhadap pola perilaku ekonomi para pengusaha. Pengusaha kini bebas untuk melakukan transaksi tanpa mengenal batas dan sekat-sekat negara. Mereka menggunakan pola transaksi ekspor impor lintas negara dan benua. Bahkan mereka mendirikan perusahaan di luar negeri, meskipun praktek afiliasi ini mendukung praktik-praktik penghindaran pajak dengan cara transfer pricing.

Ketika fenomena globalisasi merebak, orientasi dan tujuan dari transfer pricing mengalami perubahan. Fenomena globalisasi secara tidak langsung mendorong terjadinya divisionalisasi perusahaan untuk melakukan transaksi penjualan barang dan jasa di antara mereka yang sesungguhnya adalah merupakan perusahaan afiliasi. Transaksi-transaksi yang terjadi dalam lingkungan perusahaan seperti ini, akan menyulitkan dalam penentuan harga yang harus ditransfer. ${ }^{11}$ Undang-undang Nomor 36 Tahun 2008 telah memberikan otoritas perpajakan untuk menentukan kembali harga wajar transaksi antar pihak-pihak yang mempunyai hubungan istimewa (associeted enterprises) serta mewajibkannya untuk membuat perjajanjian dengan

\footnotetext{
${ }^{7}$ Departemen Pendidikan dan kebudayaaan, KBBI, (Jakarta: Balai Pustaka, 2005), hlm. 402

${ }^{8}$ As Hornby, Oxford Advanced Learner's Dictionary of Current English,(New York: Oxford University Press, 1995). Page. As Hornby, Oxford Advanced Learner's Dictionary of Current English,(New York: Oxford University Press, 1995), hlm. 394

${ }^{9}$ Gunadi, Pajak Internasional, (Jakarta: Lembaga Penerbit Fak.Ekonomi Universitas Indonesia, 2007) , Edisi Revisi, hlm. 22

${ }^{10} \mathrm{Ibid}$, , hlm. 75.

${ }^{11}$ Adrian Sutedi, Hukum Pajak, (Jakarta: Sinar Grafika, 2013), cet. 2, hlm 156
} 
Direktorat Jendral Pajak, dalam bentuk APA (advanced pricing agreement-kesepakatan harga transfer) mengenai harga wajar produk mereka. Tetapi pada tataran praktik aturan ini sulit untuk dilakukan, apalagi dilakukan pengawasannya, terutama transfer pricing yang berkaitan dengan barang-barang elektronik. Sebab harga komponen-komponen dasarnya yang mengetahui perusahaan yang bersangkutan. Berbeda halnya dengan minyak kelapa sawit sudah ada harga standar internasionalnya.

Hubungan istimewa dapat mengakibatkan kekurang wajaran pelaporan sebagai akibat pengalihan penghasilan. Hal ini terjadi karena adanya penyalahgunaan transfer harga yang dilakukan oleh perusahaan-perusahaan multinasional sebagai wajib pajak untuk merekayasa harga yang ditransfer ke perusahaan afiliasi. Hal tersebut bertujuan untuk meminimalisir atau bahkan sama sekali terhindar dari jumlah pajak yang dibayar ke negara.

Wajib pajak mengalihkan lokasi usaha dari lokasi yang tarif pajak yang tinggi ke lokasi yang tarif pajak yang rendah dalam satu divisi perusahaan, dengan cara menjual harga di bawah harga pasar atau di bawah standar dari harga yang berlaku, sehingga seolah-olah perusahaan itu mengalami kerugian dan akibatnya perusahaan tersebut membayar pajak penghasilan lebih kecil atau bahkan terbebas dari pajak. Bila perusahaan itu berdomisili atau mempunyai anak cabang di Indonesia, maka Indonesia akan mengalami kerugian akibat berkurangnya pendapatan negara dari pajak penghasilan perusahaan. ${ }^{12}$ Negara dirugikan triliunan rupiah karena praktek transfer pricing perusahaan di Indonesia. ${ }^{13}$ Modus transfer pricing ini dilakukan oleh wajib pajak perusahaan. Wajib pajak perusahaan mempunyai tenaga-tenaga yang mampu untuk membuat rekayasa administrasi dengan menaikkan ataupun menurunkan harga yang dapat mempengaruhi besaran pajak yang akan dilaporkannya atau bahkan perusahan-perusahaan bisa saja melakukan kolusi dengan oknum fiscus(petugas pajak) untuk memperkecil atau membebaskan perusahaan dari pembayaran pajak. Transfer pricing ini dalam pengertian negatif.

Penghindaran pajak menyebabkan stagnasi (macetnya) pertumbuhan ekonomi atau perputaran roda ekonomi. ${ }^{14}$ Negara menderita kehilangan pendapatan pajak dengan jumlah yang cukup signifikan, seperti dampak bagi pertumbuhan ekonomi negara Indonesia, belum lagi dampak-dampak tidak langsung yang kemudian muncul seperti berkurangnya dana/subsidi dari pemerintah. $^{15}$

\section{Kajian Hukum Islam terhadap Tax Avoidance}

a. Penghindaran Pajak dalam Lintasan Sejarah Khulafa Al-Rasyidin

Istilah pajak dalam konteks pasca terbentuknya negara modern merupakan iuran yang diwajibkan negara kepada rakyatnya-baik muslim maupun non muslim- dengan tidak mendapatkan imbal jasa secara langsung, ditentukan berdasarkan undang-undang, memberi sanksi kepada yang melanggarnya dan dipergunakan untuk kepentingan umum. Istilah pajak dengan definisi tersebut tidak pernah dikenal pada masa Rasulullah SAW., sebab Rasulullah mewajibkan kepada orang muslim dengan kewajiban membayar zakat dan kewajiban kepada non muslim dengan membayar jizyah, kharaj, dan 'usyr.

12 Ria Achmadiyah, “Transaksi Rekayasa Pajak Pada Transfer Pricing” Artikel Jurnal Maliyah, Vol. 03, No. 02, Desember 2013

${ }_{13}$ Majalah KONTAN, Edisi Tanggal 20 Juni 2012

${ }^{14}$ https://trihastutie.wordpress.com/2009/05/20 penghindaran- atau penggelapan- pajak/ diakses 3 Maret 2016

${ }^{15}$ Adrian sutedi, Ibid. , hlm. 154 
Pasca Rasulullah wafat, tepatnya pada masa kepemimpinan Umar Bin Khattab sebagai pemegang tampuk kekuasaan, telah terjadi shifting (pergeseran) pemaknaan kharaj itu sendiri. Pergeseran ini terjadi lebih disebabkan keberanian Umar Bin Khattab untuk melakukan apa yang dinamakan Ijtihad. Umar Bin Khattab memang terkenal dengan usaha-usaha untuk melakukan pembaharuan di bidang hukum Islam. Pada masa Rasulullah masih hidup, dia sering diajak oleh beliau untuk mendiskusikan persoalanpersoalan umat. Lantaran kepandaiannya, Rasulullah SAW sering menyetujui pendapatnya itu, bahkan pendapatnya sesuai dengan jawaban Allah lewat al-Qur'an yang turun kemudian.

Umar bin Khattab pernah didatangi oleh seorang laki-laki, dia berkata, "Sesungguhnya saya telah memeluk agama Islam, untuk itu bebaskan pajak bumi saya" Umar menjawab, "tidak bisa, karena tanah kamu adalah tanah taklukkan."16 Peneliti memandang, itulah awal istilah pajak untuk menyebut kharaj yang mempunyai benang merah dengan pajak dalam konteks perekonomian negara modern yang memberlakukan iuran wajib baik kepada muslim maupun non Muslim. Harta yang dipungut sebagai kewajiban yang dibebankan kepada rakyatnya kemudian diperkenalkan oleh para ulama dengan istilah dharibah. Pemaknaan dharibah ini diperluas cakupannya untuk menyebut semua jenis harta yang dipungut oleh negara yang dalam konteks perekonomian negara modern dikenal dengan istilah tax (pajak). Meskipun demikian, banyak ulama yang menyebut semua jenis harta yang dipungut oleh negara sebagai suatu kewajiban rakyat kepada negaranya dengan istilah pajak termasuk zakat dan infaq. Sehingga dengan demikian menurut hemat penulis, bahwa secara umum pajak dalam Islam yang pernah dipungut pada masa nabi dan khulafa al-rasyidun adalah jizyah, kharaj, dan 'usyr.

Zakat merupakan kewajiban kaum muslimin untuk mengeluarkan kadar harta tertentu atas harta yang dimilikinya karena telah mencapai nishab ${ }^{17}$ dan haul $^{18}$ yang telah ditentukan menurut syar'iat Islam. Pada masa Rasulullah SAW, kepatuhan umat muslim untuk membayar zakat sangat tinggi. Nyaris tidak ada umat muslim yang melakukan pembangkangan terhadap kewajiban membayar zakat. Di samping keimanan umat islam pada waktu itu sangat penuh (powerful) yang melahirkan ketaatan dan kepatuhan, mereka juga berada pada pengawasan langsung oleh Rasulullah SAW.

Dijelaskan dalam sirah nabawiyah, bahwa zakat telah diwajibkan kepada kaum muslimin pada periode dakwah Madinah, artinya Rasulullah SAW mewajibkan zakat pada tahun ke-2 setelah hijrah ke Madinah, meskipun ayat-ayat yang terkait dengan zakat

${ }^{16}$ Muhammad Rawwas Qal'ahji, Mausu'ah fiqhi Umar Ibni al-Khattab RA( Ensilkopedi Fikih Umar Bin Khattab RA), Terj. M. Abdul Mujieb AS, (Jakarta: PT. Raja Grafindo Persada, 1999), hlm. 333

${ }^{17}$ Nisab adalah jumlah batasan kepemilikan seorang Muslim selama satu tahun untuk wajib mengeluarkan zakat.

18 Pemilikan harta yang berada di pemilik sudah berlalu masanya dua belas bulan Qamariyah. Persyaratan setahun ini hanya buat ternak, uang, dan harta benda dagang, yaitu yang dapat dimasukkan ke dalam zakat modal. Tetapi hasil pertanian, buah-buahan, madu, logam mulia, harta karun, dan lain-lain yang sejenis, tidak dipersyaratkan setahun. ( Yusuf Qardhawy, Hukum Zakat, hlm.161). Lihat juga haul merupakan bentuk mufrad dari kata hu'ulun dan ahwalun yang mempunyai makna yang sama dengan al-sanah yang berarti tahun. Maksudnya dari kata itu adalah bahwa kepemilikan harta tersebut sudah berlalu (mencapai) satu tahun. Persyaratan ini hanya berlaku bagi ternak, harta simpanan dan perniagaan. Sedangkan hasil pertanian, buah-buahan dan rikaz (barang temuan) tidak ada syarat haul. 
sudah turun pada saat beliau masih di Mekah. Yusuf Qardhawy menjelaskan dalam Fiqhu al-Zakatnya bahwa:

"Zakat di Mekah adalah zakat yang tidak ditentukan batas (haul) dan besarnya (kadar zakat), tetapi diserahkan saja kepada rasa iman, kemurahan hati dan perasaan tanggung jawab seseorang atas orang lain sesama orang beriman. Sedikit sudah memadai tetapi bila kebutuhan menghendaki, zakat itu bisa lebih banyak dari itu. Kebutuhan waktu itu sesungguhnya belum memerlukan besar zakat ditentukan, karena orang-orang Islam sudah mengorbankan diri dan seluruh kekayaan mereka. Berapa besar hak orang lain belum dirasakan perlu ditentukan oleh Rasulullah Saw., tetapi cukuplah ditentukan sendiri oleh pemberi atau kebiasaan yang berlaku sesuai dengan kebutuhan pada waktu itu." 19

Umat muslim yang enggan membayar zakat akan memperoleh sanksi baik di dunia maupun di akhirat, sebagaimana Hadits yang diriwayatkan oleh Bukhari :

"Rasulullah SAW bersabda: Barang siapa yang dikaruniani oleh Allah kekayaan tetapi tidak mengeluarkan zakatnya, maka pada hari kiamat nanti ia akan didatangi oleh seekor ular jantan gundul, yang sangat berbisa dan sangat menakutkan dengan dua bintik di atas kedua matanya, lalu melilit dan mematuk lehernya sambil berteriak, saya adalah kekayaanmu yang kau timbun-timbun dulu. Nabi kemudian membaca ayat: "Janganlah orang-orang sangat kikir dengan karunia yang diberikan Allah kepada mereka itu mengira bahwa tindakannya itu baik bagi mereka, segala yang mereka kikirkan itu dikalungkan di leher mereka nanti pada hari kiamat."

Hadits tersebut memberikan gambaran sanksi yang sifatnya eskatologis, betapa pedihnya siksa yang diterima oleh orang yang enggan membayar zakat di akhirat kelak. Sedangkan hadits yang mengancam di dunia terhadap orang yang tidak mau membayar zakat, sebagaimana hadits yang diriwayatkan oleh Thabrani, Rasulullah SAW bersabda: "Golongan orang-orang yang tidak mengeluarkan zakat akan ditimpa kelaparan dan kemarau panjang."

Pasca Rasulullah SAW meningggal dan tampuk kepemimpinan umat Islam kemudian beralih ke Khalifah Abu Bakar dan telah terjadi pembangkangan umat untuk membayar zakat. Keadaan ini lebih didasarkan pada keimanan umat Islam yang agak goyah pasca meninggalnya Rasulullah SAW. Selain itu timbul fitnah yang dihembuskan oleh kaum munafiqun. Seakan-akan sepeninggal Rasulullah SAW, zakat tidak diwajibkan lagi dan, zakat tidak lebih dari ibadah sedekah biasa yang bermuatan hukum sunnah. Justru atas dasar bahwa zakat merupakan pilar dari agama Islam yang telah dipersandingkan dengan kewajiban shalat, maka sahabat Abu bakar telah mengemukakan kepada para sahabatnya yang masih ragu-ragu dalam memerangi orang yang mau melaksanakan shalat, akan tetapi tidak mau mengeluarkan zakat. Beliau berkata, "Demi Allah, saya sungguh akan memerangi orang yang memisahkan antara shalat dengan zakat." ${ }^{20}$ Pernyataan serupa juga dikemukakan oleh sahabat Umar bin Khattab ketika dimintai oleh sahabat Abu Bakar untuk memberikan pendapatnya tentang hal ini dan beliau berkata, " Demi Allah, tiada lain yang aku lihat selain Allah telah melapangkan dada Abu Bakar untuk memerangi mereka,

${ }^{19}$ Yusuf Qardhawy, , Hukum Zakat, (Terj. Didin Hafidhudin, dkk), (Jakarta: Lentera Antarnusa, 2006), hlm. 61

${ }^{20}$ Ibid., hlm. 845 
maka aku pun tahu bahwa Abu Bakar berada pada posisi yang benar." (HR. Abu Daud, shahih).Kebijakan Abu Bakar dan Umar bin Khattab bersifat tegas terhadap pelaku pembangkang zakat. Abu Bakar dengan lantang menyatakan perang terhadap mereka yang tidak mau membayar zakat.

Keadaan yang sama juga diberlakukan oleh Khalifah Umar bin Khattab ketika memberlakukan pajak seperti jizyah, kharaj dan 'usyr dengan tegas melakukan penagihan kepada mereka sesuai dengan keadaan pembayar dan penghasilannya. Diriwayatkan bahwa Umar bin Khattab pernah ingin menghukum Said bin Amir, gubernur Himsh ketika terlambat membayar pajak, Umar berkata, "mengapa kamu terlambat membayar pajak?" maka Said menjawab, "engkau memerintahkan kami agar petani tidak membayar lebih dari empat dinar, dan kami tidak menambahnya, akan tetapi kami terlambat menunggu penghasilan mereka." Umar berkata, "aku tidak akan memecatmu selama engkau hidup" Umar juga pernah memberi peringatan kepada Amru bin Ash sebagai gubernur Mesir pada masa itu dan mengirimnya surat agar segera membayar kewajiban pajaknya yang terlambat dibayarkan. Di dalam surat tersebut, Umar berkata kepada Amru bin Ash: "aku tahu bahwa ada pajak yang harus engkau bayar, maka penuhilah pajak dan ambillah dari haknya". ${ }^{22}$ Kedua dialog antara Umar bin Khattab dengan Said bin Amr, serta Umar bin Khattab dengan Amr bin Ash menunjukkan sikap sangat tegas yang ditunjukkan oleh sang Khalifah terhadap pembantu-pembantunya yang terlambat menyetorkan uang pajaknya. Meskipun demikian, Khalifah Umar bin Khattab sangat menjunjung nilai keadilan kepada rakyatnya manakala tanah kharaj yang diolah mengalami gagal panen, irigasi bermasalah, kerugian ataupun hal-hal yang di luar batas kemampuannya yang mempengaruhi hasil panen tanah kharaj tersebut.

Al-Mawardi dalam Mannan terkait dengan hal ini mengatakan:

Faktor yang menentukan kemampuan memikul kharaj (pajak bumi) sebagai berikut "Orang yang menaksir kharaj atas sebidang tanah harus mempertimbangkan kemampuan tanah, yang berbeda menurut tiga faktor, tiap faktor sedikit banyaknya mempengaruhi jumlah kharaj. Salah satu faktor yang berkaitan dengan tanah itu sendiri adalah mutu tanah yang dapat menghasilkan panen yang besar, atau cacat yang menyebabkan hasil panen yang besar, atau cacat yang menyebabkan hasil yang kecil. Faktor kedua berhubungan dengan panen, karena padi-padian dan buah-buahan berbeda harganya, pada yang lebih tinggi harganya dari pada yang lain, dan karena itu kharaj harus ditaksir sesuai dengan yang itu. Faktor ketiga mengenai cara irigasi karena panen yang dihasilkan dengan system irigasi air yang dipikul dengan hewan atau dperoleh dengan kincir, tidak dapat dikenakan kharaj yang sama dengan panen yang dihasilkan oleh tanah yang diairi oleh air yang mengalir atau air hujan. ${ }^{23}$

Selanjutnya Mannan mengatakan:

Selama kualitas tanah tetap sama dengan cara irigasi dan keuntungannya, maka pajaknya tidak bertambah atau berkurang. Tetapi kalau gangguan pada cara irigasi

${ }^{21}$ Jaribah ibn Ahmad Al-Haritsi. Terj. Asmuni Sholihan, Fikih Ekonomi Umar bin Al Khattab.( Jakarta: Khalifa, 2006), hlm. 627

${ }^{22}$ Ibid., hlm. 628

23 M.A. Mannan, Ekonomi Islam: Teari dan praktik, (terj. Potan Harahap), (Jakarta: PT Intermasa, 1992), hlm. 251 
disebabkan oleh faktor alam dan merugikan si pengolah, maka Negara harus mengusahakan perbaikan dan si pemiilik tanah tidak dikenakan kharaj selama tanah tersebut tidak dapat ditanami. Demikian juga dalam hal perubahan tetap dalam cara irigasi yang hasilnya merugikan tanah, Negara mungkin atau bahkan tidak menaikkan tingkat kharaj. Bila seluruh panen musnah, atau karena beberapa faktor di luar kuasa si pemilik maka ia tidak dikenakan kharaj. Bila seseorang tidak mampu membayar pajak, maka ia diberi waktu sehingga keuangannya membaik. Tapi bila seseorang punya suatu i'tikad tidak baik untuk tidak membayar pajak kharaj, maka iapun dipaksa untuk membayar pajak. Demikian kita lihat bahwa pajak kharaj bukan saja progresif tetapi juga bersifat luwes. Dan pajak ini konsisten dengan peraturan modern perpajakan. Praktek modern dalam memberikan pembebasan pajak dalam hal yang khusus dan layak, atau menyita harta benda si pengelola karena tidak membayar pajak, tampaknya berasal dari administrasi sesungguhnya dari pajak kharaj. ${ }^{24}$

Umar bin Khattab sebagai sosok khalifah yang mempunyai pemikiran sangat revolusioner terhadap hukum Islam telah menempatkannya sebagai seorang khalifah yang terkenal cerdas, pemberani, tegas, dan mampu menangkap pesan-pesan universal dalam alQur'an maupun al-Hadits untuk mewujudkan hokum Islam yang berkeadilan. Hal tersebut menunjukan apa yang dilakukan oleh Abu Bakar dan Umar bin Khatatab terkait dengan perilaku umat Islam untuk tidak membayar pajak adalah bukti sejarah bahwa perilaku tersebut bertentangan dengan hukum Islam. Negara sebagai organisasi yang mempunyai kewenangan pelaksanaan kemaslahatan umum dapat melakukan upaya-upaya penagihan, pemaksaan, atau dengan memberi sanksi berupa penahanan dan pemidanaan kepada wajib pajak yang terbukti melakukan penghindaran dengan niat motifasi I'tikad tidak baik.

b. Wajib Pajak tidak Beritikad tidak Baik

Peranan pajak dalam perekonomian Negara modern menjadi sangat penting. Pajak dikonstruksikan sebagai sumber penerimaan utama negara. Lebih-lebih ketika sumber penerimaan dari sektor migas melemah dan tidak dapat diharapkan lagi, maka pajak sebagai sumber primadona. Berkembang dan terpuruknya negara berawal dari ada atau tidaknya pajak. Dalam teori kebijakan sumber pendapatan negara modern, bahwa pajak diposisikan sebagai sumber pendapatan yang sangat vital. ${ }^{25}$

Berkaitan dengan pernyataan tersebut, adagium bahwa pajak merupakan darah kehidupan (life blood) untuk keberlangsungan kehidupan sebuah negara adalah sebuah realitas yang tidak dapat dipungkiri, tidak memandang apakah negara itu bentuknya otokrasi maupun berbentuk demokrasi hampir dapat dipastikan tidak akan mampu bertahan hidup dalam menjalankan roda pemerintahannya tanpa mengandalkan sumber pendapatan negara berupa pajak. ${ }^{26}$ Hal inilah yang menjadi sumber kehawatiran Yusuf Qardhawy terhadap negara-negara Islam modern ketika zakat tidak mampu untuk mengcover kebutuhan-kebutuhan negara dalam menghadapi kompleksitas kebutuhan yang harus dipenuhi untuk kepentingan umum. Sementara sumber-sumber lain pula semisal minyak

${ }^{24}$ Ibid.

${ }^{25}$ Muhammad dan Ali Murtadho Emzaed, Pajak Dalam Bingkai Syari'ah, (Yogyakarta: Pustaka Pelajar, 2014), Cet. I, hlm. 105

${ }^{26} \mathrm{Ibid}$. 
bumi juga tidak mencukupi menutupi pembiayan Negara. Jika negara Islam modern dibiarkan tanpa pajak, maka dapat dipastikan dalam waktu singkat akan kehilangan kemampuannya, lambat-laun akan menjadi lemah, lebih-lebih timbulnya ancaman militer terhadapnya. ${ }^{27}$

Dalam perspektif niat bahwa transfer pricing dengan motivasi wajib pajak untuk mengambil manfaat pajak (tax benefit) merupakan tindakan kesengajaan. Ulama sepakat bahwa tempat niat adalah hati, bila niat hanya diucapkan ke dalam lisan saja belum dianggap cukup $^{28}$, tanpa adanya kesadaran dalam hati untuk menghadirkan suatu perbuatan. Teori tersebut menyebutkan bahwa, niat merupakan awal keinginan yang melandasasi aksi seseorang untuk melakukan atau tidak melakukan perbuatan. Aktivitas niat sifatnya tidak nampak dan yang nampak adalah akibat dari niat yang sudah terealisir ke dalam perbuatan.

Titik kritis yang harus dicermati dari perilaku penghindaran pajak dengan menggunakan cara transfer pricing ini adalah rekayasa wajib pajak untuk menaikkan harga atau menurunkan harga dari harga yang wajar atas penjualan barang atau jasa kepada perusahaan afiliasi/divisi dengan indikasi kerugian. Indikasi kerugian tersebut menyebabkan wajib pajak tidak terbebani pajak. Aksi penjualan atas barang dan jasa yang direkayasa tersebut dilakukan secara sadar, sistematis dan terencana dengan syarat motif utamanya adalah untuk membebaskan pajak. Kita telah mafhum bahwa motifasi utama transfer pricing adalah untuk menghindar pajak, dengan kata lain wajib pajak tidak memiliki itikad untuk membayar pajak.

Peran hati bagi seluruh anggota badan ibarat raja bagi prajuritnya. Semua bekerja berdasarkan perintah. Semua tunduk kepadanya, karena perintah hatilah kebaikan dan keburukan, kepatuhan dan penyelewengan itu terjadi. ${ }^{29}$ Hadirnya niat dan motivasi dalam perbuatan seorang dalam pandangan hukum Islam itu sangat penting, sebab niat itu menjadi syarat perbuatan itu berpahala atau tidak, sah atau bathal, shahih atau fasad, dan disengaja ('amd) atau karena kealpaan ( khatha'). Segala perbuatan itu tergantung pada niatnya. Dan seseorang akan memperoleh sesuatu itu sesuai dengan apa yang diniatkannya itu.

Dalam kajian ilmu manajemen, istilah niat/motivasi sangat berpengaruh pada pola pikir dan tingkah laku manusia. Muhammad dalam tesis ${ }^{30}$ nya telah mendefinisikan motifasi adalah masalah yang esensial yang mewarnai pemikiran, kemauan seseorang dalam menentukan dan menetapkan suatu kegiatan guna mencapai tujuan (goal) tertentu. Hal tersebut merupakan bagian potensial yang dapat mengarahkan potensi dan daya manusia dengan jalan menghidupkan dan membangkitkan semangat seseorang atau kelompok.

Sehubungan dengan itu, Owen mengemukakan bahwa secara garis besar motivasi mempunyai fungsi yang sangat fundamental dalam kehidupan manusia, yaitu:

${ }^{27}$ Yusuf Qardhawyy, Hukum Zakat, Ibid. hlm. 1075

${ }^{28}$ Wahbah Zuhaily, Fiqih Islam Wa Adillatuhu, (Jakarta: Gema Insani Pers, 2011), hlm.141

${ }^{29}$ Ibnu Rajab Al Hambali et.al., Tazkiyatun nafs: Konsep Penyucian Jiwa Menurut Ulama Salafushshalih, (Terj. Imtihan As-Syafi'i), (Solo: Pustaka Arafah, 2012), Cet. 25, hlm. 25

${ }^{30}$ Muhammad, Perbankan Islam: Visi dan Aksi, (tesis : Pasca Sarjana Universits Muhammmadiyah Malang, 1999), hlm. 92 
1. Mendorong manusia untuk berbuat sesuatu, artinya motivasi adalah keadaaan dalam diri seseorang yg mengaktifkan atau menggerakkan orang tersebut sehingga terdorong untuk melakukan sesuatu. Dalam konteks ini, motivasi bagaikan motor yang mnegantarkan seseorang untuk sampai pada suatu tujuan.

2. Menentukan arah perbuatan seseorang dalam melakukan suatu perbuatan memiliki orientasi atau tujuan, artinya seseorang terdorong untuk melakukan sesuatu karena mengetahui arah dan tujuan. Tercapainya tujuan tergantung pada kuat atau tidaknya daya dorong (motivasi). Apabila motivasinya kuat maka tujuan tersebut akan tercapai, sebaliknya, apabila motivasinya lemah, maka tipis kemungkinan untuk mencapai tujjuan.

3. Menyeleksi perbuatan, fungsi ini memusatkan perhatian dan fikiran seseorang untuk memilih dan memilah suatu kegiatan atau perbuatan yang terjadi dalam waktu yang bersamaan sehingga dapat diputuskan bahwa perbuatan yang dilakukan adalah perbuatan yang didasari oleh motivasi.

Paparan di atas menjelaskan bahwa betapa pentingnya arti sebuah niat dan motivasi untuk menghadirkan suatu tindakan dalam melakukan aksi transfer pricing. Hal ini penting untuk untuk menjawab pertanyaan "why", mengapa wajib pajak melakukan perilaku tax avoidance? Adakah niat / motivasi wajib pajak dilandasi oleh suatu itikad tidak baik (not good faith). Niat/motifasi menghindar pajak merupakan manifestasi dari itikad tidak baik.

Itikad tidak baik secara semantik adalah oposite (lawan kata) dari I'tikad baik. Secara substansi bahwa Itikad baik ${ }^{31}$ merupakan perilaku terpercaya, jujur, bersih, memenuhi apa yang menjadi tanggung jawab yang ditunjukkan oleh sesorang. Istilah Itikad baik ini pada awalnya merupakan monopoli istilah dalam hukum perdata. Pada pasal 1338 ayat (3) BW mengatakan bahwa; "Persetujuan-persetujuan dalam perjanjian harus dilaksanakan dengan itikad baik." Itikad baik menjadi prasyarat utama yang harus dipegang oleh para pihak yang akan melakukan kontrak perjanjian dalam perkara keperdataan, akan tetapi itikad baik ini telah menjadi asas hukum yang sifatnya publik, sehingga asas itikad baik telah berkembang menjadi asas hukum publik.

Menurut Scholten bahwa penggunaan asas yang semula khusus yang kemudian berkembang menjadi asas hukum yang publik adalah sesuatu yang lumrah terjadi dikarenakan penilaian value/norm baik dan buruk yang sifatnya umum pula. Kebaikan dan keburukan dalam dogmatik hukum adalah sifatnya universal.

Praktik itikad baik dalam hubungan jual beli misalnya, penjual harus menyatakan keadaan, bentuk, sifat, cacat atau tidak suatu barangnya yang dapat menginformasikan kepada pembeli untuk memutuskan pembelian atau tidak. Penjual tidak menyembunyikan sesuatau keadaan barang kepada pembeli. Penjual berkewajiban menginformasikan

31 Itikad baik merupakan istilah yang familiar dalam ilmu hukum terutama hukum perdata. Meskipun penggunaan istilah i'tikad baik sudah menjadi istilah yang universal sifatnya. Kajian dalam epistemologi ilmu hukum i'tikad baik merupakan doktrin atau asas yang berasal dari ajaran bona fides dalam Hukum Romawi.Itu sebabnya asas itikad baik memang lebih memiliki kedekatan dengan Sistem Civil Law ketimbang dengan Sistem Common Law. Fides berarti sumber yang bersifat religius, yang bermakna kepercayaan yang diberikan seseorang kepada orang lainnya, atau suatu kepercayaan atas kehormatan dan kejujuran seseorang kepada orang lainnya. Bona fides mensyaratkan adanya itikad baik dalam perjanjian yang dibuat oleh orang-orang Romawi.Lihathttps://wisuda.unud.ac.id/pdf/1292462008BAB\%20II\%20Ngurah\%20Wahyu\%20Resta\%20.pdf 
(Mededeling plicht) keadaan barangnya dan pembeli berkewajiban untuk menelitinya (Onderzoekplicht), sehingga tidak merasa dirugikan ketika terjadi kontrak/akad pembelian tersebut di kemudian hari.

Mengapa itikad baik menjadi motif yang sangat penting dalam persoaalan tax avoidance ini? Pajak bila dihadapkan pada wajib pajak sebagai subyek pajak adalah merupakan hubungan kontraktual hutang piutang kepada negara sebagai kompensasinya dalam mendapatkan prestasi (manfaat) secara tidak langsung. Warga Negara sebagai wajib pajak akan memperoleh perlindungan, keamanan, fasilitas-fasilitas umum yang dapat dimanfaatkan bersama-sama dengan warga yang lain. Hak perlindungan, keamanan, perdamaian, pemanfaatan fasilitas-fasilitas umum, dan lain-lain akan dinikmati oleh warga negara, baik yang mempunyai kewajiban bayar pajak atau tidak. Wajib pajak harus melunasi pajak terutangnya kepada negara sebagaimana halnya orang-orang pada umumnya yang berperan sebagai subyek hukum harus melunasi utangnya ketika sudah jatuh tempo.

Wajib pajak adalah orang atau badan hukum baik perorangan maupun perusahaan yang telah memenuhi persyaratan untuk membayar pajak kepada negara. Apabila terjadi wan prestasi (ingkar janji) yang dilakukan wajib pajak maka wajib pajak dapat dikenai sanksi sesuai dengan peraturan perundang-undangan yang berlaku. Meskipun perilaku tax avoidance yang dilakukan oleh wajib pajak belum sampai pada wilayah otoritas pajak untuk memberlakukan law enforcement karena memang wajib pajak belum melaporkan perhitungan pajaknya secara self assesment system (sistem pelaporan wajib pajak mandiri ) yang kemudian keluarlah Surat Pemberitahuan Tahunan (SPT), akan tetapi wajib pajak di sini telah melakukan serangkaian perilaku tax avoidance. Ada sesuatu yang disembunyikan oleh wajib pajak. Wajib pajak telah melakukan aksi ketidakadilan, tidak ada itikad baik dalam sistem pelaporan pajaknya.

Secara garis besar ada dua macam sistem yang diberlakukan negara dalam memungut pajak kepada warga negaranya dalam perpajakan. Sistem itu adalah official Assessment system dan Self Assessment System. Official Assessment System adalah sistem yang diberlakukan negara dalam memungut pajak kepada warga negaranya bahwa penentuan, perhitungan pajak dilakukan oleh negara, sedangkan Self Assessment system merupakan sistem yang diberlakukan oleh negara dengan memberikan kepercayaan penuh kepada wajib pajak untuk melakukan penghitungan, pelaporan, dan pembayaran pajak terutangnya secara mandiri. Adapun fiscus mempunyai fungsi untuk melakukan pembinaan, pengawasan, dan pembimbingan kepada wajib pajak dalam melaksanakan kewajibannya dalam membayar pajak pada negara. Penilaian terhadap sistem ini sangat baik bila wajib pajak mempunyai kesadaran tinggi untuk melakukan pelaporan mandiri mengenai pajak terutangnya kepada negara secara sukarela (voluntary tax compliance). Akan tetapi sebaliknya bila wajib pajak tidak mempunyai kesadaran yang tinggi untuk membayar pajak, yang terjadi adalah perilaku penghindaran pajak itu sendiri. Pada gilirannya akan menjadi sumber get trouble bagi penerimaan Negara. Sistem ini tertuang jelas di dalam Undang-Undang Perpajakan. 
Menurut Ilyas dan Burton dalam Audia Citra Permita et.a ${ }^{32}$, prinsip self assessment secara jelas tampak dalam ketentuan Pasal 12 Undang-Undang Nomor 6 Tahun 1983 tentang Ketentuan Umum dan Tata Cara Perpajakan yang telah diubah dengan Undangundang No 16 Tahun 2009 (Undang-undang KUP) pada dasarnya memiliki makna, yaitu:

1. Agar semua wajib pajak bersifak aktif di dalam melaksanakan kewajiban perpajakannya tanpa perlu menunggu adanya surat ketetapan pajak yang akan dikeluarkan oleh petugas pajak (fiskus).

2. Penghitungan jumlah pajak yang dibayar untuk sementara dianggap sebagai perhitungan menurut ketentuan yang berlaku.

3. Fiskus memiliki kewenangan untuk melakukan penghitungan jumlah pajak yang telah dilaporkan wajib pajak sepanjang fiskus memiliki data bahwa wajib pajak belum melaksanakan penghitungan dengan benar. Surat ketetapan pajak akan diterbitkan setelah melalui proses pemeriksaan dengan cara-cara yang diatur dalam UndangUndang Pajak.

Indonesia telah memberlakukan Self Assesment system semenjak reformasi perpajakan digulirkan pada tahun 1984. Secara aksiologis bahwa negara memberlakukan sistem self assessment ini lebih didasari oleh keinginan negara untuk mengikutsertakan warga negara dalam pembangunan nasional yang digulirkan pemerintah. Warga negara diharapkan partisipasinya secara nyata dalam proses pembangunan yang digalakkan oleh negara melalui keikutsertaannya lewat pajak oleh karena pembangunan membutuhkan banyak biaya. Negara memiliki kewenangan untuk memungut pajak dari warganya. Tujuan utama dari pembangunan adalah untuk kemakmuran rakyat. Oleh karena itu negara memungut pajak kepada warga negara adalah sesuatu hal yang lumrah yang mengikutsertakan rakyat untuk andil bersama-sama dalam pembiayaan pembangunan dengan memenuhi kewajiban perpajakannya dengan baik dan benar.

Sistem ini sebenarnya memberikan kemudahan kepada wajib pajak untuk melaksanakan kewajibannya kepada negara. Akan tetapi sistem ini mempunyai resiko yang sangat tinggi terhadap kepatuhan bayar pajak. Perilaku tax avoidance ini adalah efek dari sistem tersebut. Jadi perilaku tax avoidance ini terjadi sebelum wajib pajak ditetapkannya sebagai wajib pajak yang mempunyai pajak terutang yang diketahuinya dari Surat Pemberitahuan Pajak (SPT). Pada titik inilah sesungguhnya merupakan titik tolak para penegak hukum untuk mengendus niat i'tikad tidak baik para pelaku tax avoidance ini. Apalagi wajib pajak tersebut dikenal sebagai pemilik perusahaan besar, namun pada kenyataannya membayar pajaknya kecil.

Menurut hemat peneliti, dengan adanya serangkaian perbuatan untuk menghindari pajak meskipun hukum positif tentang perpajakan mengkategorikan tindakan yang legal (legal action), akan tetapi perbuatan itu sudah masuk pada kategori perbuatan yang bertentangan dengan norma hukum Islam. Kecuali niat/ motif dan itikad tidak baik yang terbersit dalam hati tanpa menghadirkan dalam ucapan dan perbuatan wajib pajak. Sesuai dengan Sabda Rasulullah SAW: "Inna allaha ta'ala tajawaza liummatii 'ammaa hadatsat biha anfusahaa ma lam tatakallam bihi au ta'mal bihi." ${ }^{33}$ (sesunggguhnya Allah SWT

${ }^{32}$ Audia Citra Permita et. Al., Pengaruh Persepsi Wajib Pajak Orang Pribadi atas Pelaksanaan Self Assessment System terhadap Tindakan Tax Evasion di Kota Padang, www.multiparadigma.lecture.ub.ac.id, diakses tanggal 30 September 2016

${ }^{33}$ Wahbah Az-Zuhaily, Ibid., hlm. 135 atau lihat As-Suyuthi, Al-Asybah wan-Nazha 'ir, hlm. 29 
mengampuni ummatku dari apa saja yang terbertik dalam hatinya, selagi belum terucap atau belum terlaksana.)

Setidaknya Yusuf Qardhawy ${ }^{34}$ mencatat ada lima bahaya yang diakibatkan oleh praktik penghindaran pajak ini:

1. Membahayakan keuangan Negara dimana pendapatan pajak akan berkurang.

2. Membahayakan kepada wajib pajak lainnya yang tidak dapat melepaskan diri dari pajak atau karena ia tidak senang melarikan diri sehingga mereka menanggung beban pajak, sedangkan yang lainnya terlepas daripadanya. Sehingga terjadi ketidakadilan dalam pembayaran beban pajak.

3. Menyebabkan naiknya tarif pajak yang ada atau ditetapkannya kewajiban pajak baru untuk menggantikan kekurangan dari hasil pajak akibat dari banyaknya yang menghindari pajak.

4. Hal itu berbahaya bagi kepentingan masyarakat, di mana berkurangnya keuangan Negara menyebabkan terbengkelainya rencana yang bermanfaat.

5. Ini menyebabkan semua merosotnya akhlak karena merajalelanya berbagai penipuan akibat rusaknya jiwa, hilangnya kejujuran dan lemah ikatan solidaritas antara pribadi dan masyarakat

\section{Kesimpulan}

Perilaku tax avoidance dengan cara transfer harga ke perusahaan afiliasi telah bertentangan dengan hukum Islam, sebab terdapat korelasi antara niat dengan perbuatan memindah lokasi penjualan barang dan jasa(transfer pricing) ke negara yang memberlakukan bebas pajak dengan motifasi utamanya adalah menghindar pajak. Meskipun tidak menimbulkan kerugian antara penjual dan pembeli karena dilakukan oleh perusahaan afiliasi, akan tetapi negara yang mendapat kerugian pendapatan dari sektor pajak. Pada masa Rasulullah SAW hukuman bagi pengelak, penghindar dan pembangkang zakat adalah sanksi dunia dan akhirat, sementara pada masa Khalifah Abu Bakar dan Khalifah Umar Bin Khattab mereka ditagih dan diperangi.

\footnotetext{
${ }^{34}$ Yusuf Qardhawy, Ibid., hlm. 1095
} 


\section{DAFTAR PUSTAKA}

Adrian Sutedi, 2013, Hukum Pajak, Sinar Grafika, Jakarta.

As Hornby, 1995, Oxford Advanced Learner's Dictionary of Current English, Oxford University Press, New York.

Audia Citra Permita et. Al., Pengaruh Persepsi Wajib Pajak Orang Pribadi atas Pelaksanaan Self Assessment System terhadap Tindakan Tax Evasion di Kota Padang, www.multiparadigma.lecture.ub.ac.id, diakses tanggal 30 September 2016

Gunadi, 2007, Pajak Internasional, Lembaga Penerbit Fakultas Ekonomi Universitas Indonesia, Jakarta.

https://trihastutie.wordpress.com/2009/05/20 penghindaran- atau penggelapanpajak/https://wisuda.unud.ac.id/pdf/1292462008BAB\%20II\%20Ngurah\%20Wah yu\%20Resta\%20.pdf

Ibnu Rajab Al-Hambali et.al., 2012, Tazkiyatun Nafs: Konsep Penyucian Jiwa Menurut Ulama Salafushalih, Pustaka Arafah, Solo.

Jaribah ibn Ahmad Al-Haritsi Terjemahan Asmuni Sholihan, 2006, Fikih Ekonomi Umar bin Al Khattab, Khalifa, Jakarta.

M. A. Mannan, 1992. Ekonomi Islam : Teori dan Praktik, PT. Intermasa, Jakarta.

Majalah KONTAN, Edisi Tanggal 20 Juni 2012

Muhammad, 1999, Perbankan Islam: Visi dan Aksi, tesis, Pasca Sarjana Universitas Muhammmadiyah Malang, Malang.

Muhammad dan Ali Murtadho Emzaed, 2014, Pajak dalam Bingkai Syari'ah, Pustaka Pelajar, Yogyakarta.

Muhammad Rawwas Qal'ahji, 1999, Mausu'ah fiqhi Umar Ibnu al-Khattab RA (Ensiklopedi Fikih Umar Bin Khattab RA), PT. Raja Grafindo Persada, Jakarta.

Reskino, Rini, dan D. Novitasari, Persepsi Mahasiswa Akuntansi Mengenai Penggelapan Pajak. Makalah disajikan dalam Simposium Nasional Perpajakan IV. Bangkalan. 2013.

Ria Achmadiyah, Transaksi Rekayasa Pajak Pada Transfer Pricing, Artikel Jurnal Maliyah, Vol. 03, No. 02, Desember 2013.

Wahbah Zuhaily, 2011, Fiqih Islam wa Adillatuhu, Gema Insani, Jakarta.

Yusuf Qardhawy, 2006, Hukum Zakat, Lentera Antarnusa, Jakarta. 
